\title{
R. Rossi, Arte e schizofrenia: un lavoro comune
}

\section{Marco Stupazzoni}

\section{OpenEdition}

\section{Journals}

\section{Edizione digitale}

URL: http://journals.openedition.org/studifrancesi/6013

DOI: $10.4000 /$ studifrancesi.6013

ISSN: 2421-5856

\section{Editore}

Rosenberg \& Sellier

\section{Edizione cartacea}

Data di pubblicazione: 1 mai 2011

Paginazione: 187

ISSN: 0039-2944

\section{Notizia bibliografica digitale}

Marco Stupazzoni, «R. Rossi, Arte e schizofrenia: un lavoro comune», Studi Francesi [Online], 163 (LV | I) |

2011, online dal 30 novembre 2015, consultato il 09 janvier 2021. URL: http://

journals.openedition.org/studifrancesi/6013 ; DOI: https://doi.org/10.4000/studifrancesi.6013

Questo documento è stato generato automaticamente il 9 janvier 2021.

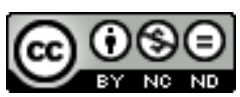

Studi Francesi è distribuita con Licenza Creative Commons Attribuzione - Non commerciale - Non opere derivate 4.0 Internazionale. 


\title{
R. Rossi, Arte e schizofrenia: un lavoro
}

\section{comune}

\author{
Marco Stupazzoni
}

\section{NOTIZIA}

R. RossI, Arte e schizofrenia: un lavoro comune, «Giornale italiano di Psicopatologia» $\mathrm{n}^{\circ} 14$, 2008, pp. 3-9.

Pur sottolineando la non-sovrapponibilità assoluta tra arte e schizofrenia, l'A. intende ricercare, in questo studio, le componenti e le funzioni disgreganti e destrutturanti che sono comuni tanto alla creazione artistica quanto alla patologia schizofrenica. Fornendo alcuni esempi che rimandano all'arte narrativa, che l'A. ritiene fondata sulla «struttura depressiva» (p. 6), è citato Balzac, definito come «l'iniziatore della psichiatria», di cui viene riportato un estratto delle Femme de trente ans dove è protagonista Mme d'Aiglemont che Rossi ritiene «l'esempio più armonico, più stilisticamente ordinato [...] di come un giovane psichiatra dovrebbe stilare la storia di una depressione» (ibid.). 